\title{
Ferrite Magnet Effect terhadap Emisi Gas Buang Four Stroke Engine 125 CC
}

\author{
Yan Dwi Pratama ${ }^{*}$, Firman Yasa Utama ${ }^{1}$ \\ 1,2 Teknik Mesin - Universitas Negeri Surabaya \\ e-mail address : yandwi0109@gmail.com,
}

\begin{tabular}{|c|c|}
\hline Keywords: & Abstrak: \\
\hline $\begin{array}{l}\text { Magnet, Ferrite Magnet, } \\
\text { Emisi Gas Buang, Four } \\
\text { Stroke Engine }\end{array}$ & $\begin{array}{l}\text { Emisi gas buang merupakan zat/unsur dari pembakaran didalam ruang bakar } \\
\text { yang dilepas ke udara yang ditimbulkan oleh kendaraan bermotor, sehingga } \\
\text { dapat menimbulkan dampak terhadap lingkungan, terutama dapat } \\
\text { menyebabkan polusi udara, lingkungan, dan perubahan iklim global. Untuk } \\
\text { mengatasi permasalahan tersebut diperlukan cara lain agar dapat menghemat } \\
\text { bakar yang sederhana, bahan relatif murah, dan mudah didapatkan. Salah satu } \\
\text { caranya menggunakan ferrite magnet untuk mengurangi emisi gas buang yang } \\
\text { dihasilkan. Metode yang digunakan dalam penelitian ini berdasarkan standar } \\
\text { SNI 19-7118.3-2005 dengan pengukuran emisi gas buang pada kendaraan } \\
\text { berbahan bakar bensin yang dilakukan pada kondisi idle. Namun untuk } \\
\text { penelitian dapat juga dilakukan pengujian pada bukaan katup (throttle) yang } \\
\text { berubah yang menggunakan metode pengujian kecepatan berubah dengan } \\
\text { katup (throttle) terbuka penuh. Dari penelitian ini diperoleh bahwa } \\
\text { pemasangan ferrite magnet pada kendaraan four stroke engine } 125 \text { cc dapat } \\
\text { mempengaruhi emisi gas buang kendaraan yang dihasilkan saat menggunakan } \\
\text { bahan bakar pertalite maupun pertamax. Kadar emisi gas buang yang didapat } \\
\text { adalah } 562 \text { ppm vol (ferrite pertalite) untuk gas HC, } 8,53 \% \text { untuk gas CO } \\
\text { (pertalite/pertamax), 10,8\% untuk gas } \mathrm{CO}_{2} \text { (ferrite pertamax), dan untuk gas } \\
\mathrm{O}_{2} \text { kadar emisinya sebesar } 14,91 \% \text { (ferrite pertalite). }\end{array}$ \\
\hline
\end{tabular}

\section{PENDAHULUAN}

Emisi gas buang merupakan zat/unsur dari pembakaran didalam ruang bakar yang dilepas ke udara yang ditimbulkan oleh kendaraan bermotor. Gas buang hasil dari pembakaran atau uap bahan bakar bensin ini dapat dibagi menjadi tiga macam yaitu $\mathrm{CO}$ (Carbon Monoxide), HC (Hydrocarbon) dan NOx (Nitrogen Oxide). Bila bensin terbakar maka akan terjadi reaksi dengan oksigen membentuk $\mathrm{CO}_{2}$ (Carbon Dioxide) dan $\mathrm{H}_{2} \mathrm{O}$. Gas buang atau polutan yang paling sering diperhatikan adalah $\mathrm{CO}, \mathrm{HC}, \mathrm{CO}_{2}$ dan $\mathrm{O}_{2}$. Dua gas yang disebutkan terakhir bukan merupakan polutan tetapi terus diperhatikan karena menjadi indikator efisiensi bahan bakar [1].

Seperti yang kita ketahui gas-gas tersebut merupakan sumber pencemar yang dapat menimbulkan dampak terhadap lingkungan, terutama dapat menyebabkan polusi udara, lingkungan, dan perubahan iklim global. Telah ada berbagai cara untuk mengurangi dampak emisi gas buang yang dihasilkan kendaraan seperti penambahan catalytic converter pada knalpot, memodifikasi knalpot agar dapat mereduksi emisi gas buang yang dihasilkan, hingga penambahan zat tertentu pada tangki bahan bakar untuk mengurangi emisi gas buang [2]. Salah satu cara lain untuk mengurangi emisi gas buang adalah menggunakan ferrite magnet pada saluran bahan bakar.

Ferrite magnet merupakan suatu material yang dapat menghasilkan medan magnet tanpa harus diberi arus listrik yang mengalir dalam sebuah kumparan atau solenoida untuk mempertahankan medan magnet yang dimilikinya. Disamping itu, magnet permanen jenis ini juga dapat memberikan medan yang konstan tanpa mengeluarkan daya yang kontinyu [3].

Ferrite magnet menggunakan metode pengionisasi positif dan negatif pada bahan bakar kendaraan. Ketika bahan bakar mengalir pada pipa saluran bahan bakar sebelum masuk ke dalam carburator/injektor, ion positif dan negatif mengalir secara acak (tak beraturan). Pada saat melalui medan magnet, ion positif akan tertarik oleh kutub negatif magnet sedangkan untuk ion

https://dx.doi.org/10.20961/mekanika.v19i1.40011 
negatif akan tertarik oleh kutub positif magnet sehingga ion positif dan negatif yang mengalir secara acak akan menjadi teratur setelah melewati medan magnet tersebut. Dengan metode ini, bahan bakar akan lebih mudah dibakar didalam ruang bakar sehingga gas buang yang dihasilkan dari kendaraan dapat dimaksimalkan [4].

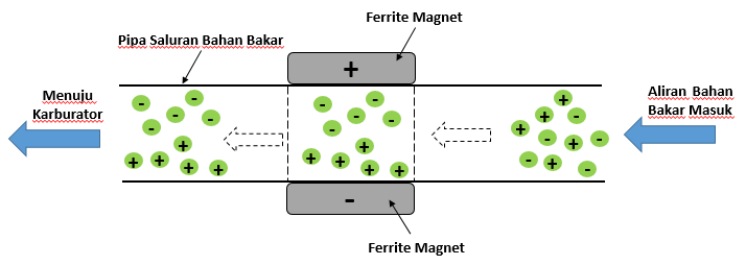

Gambar 1. Prinsip Ferrite Magnet dalam pipa saluran bahan bakar

\section{METODOLOGI PENELITIAN}

\subsection{Jenis Penelitian}

Penelitian ini merupakan jenis penelitian eksperimen (eksperimental research) yang bertujuan untuk mencari pengaruh pemasangan ferrite magnet pada saluran bahan bakar dengan bahan bakar pertalite dan pertamax terhadap emisi gas buang four stroke engine $125 \mathrm{cc}$ yang meliputi HC (Hydrocarbon), CO (Carbon Monoxide), $\mathrm{CO}_{2}$ (Carbon Dioxide), dan $\mathrm{O}_{2}$.

\subsection{Objek Penelitian}

Pada penelitian ini obyek yang digunakan adalah sepeda motor Honda Supra X 125R tahun 2011 menggunakan ferrite magnet dari TDK yang diletakkan diposisi sesudah tangki bahan bakar dan sebelum karburator dengan menggunakan bahan bakar pertalite dan pertamax.

\subsection{Rancangan Eksperimen}

Dalam penelitian ini, untuk mengetahui pengaruh pemasangan ferrite magnet pada saluran bahan bakar terhadap emisi gas buang four stroke engine $125 \mathrm{cc}$, saluran bahan bakar akan dipasang ferrite magnet. Pemasangan ferrite magnet yang berjumlah dua biji dipasang pada fuel hose dengan ketentuan 1 diletakkan

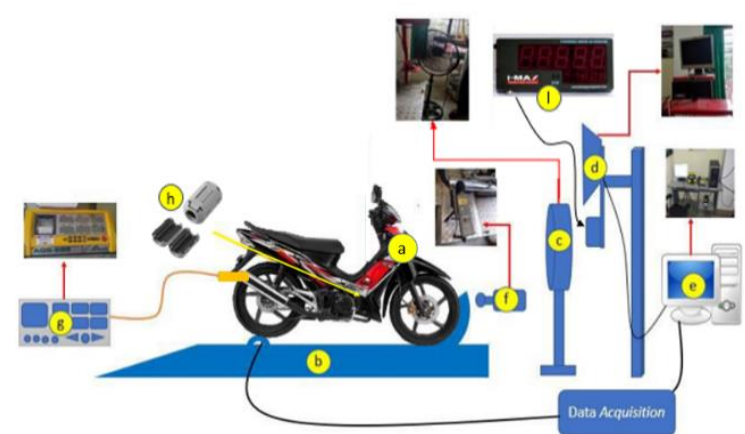

sesudah tangki bahan bakar dan yang satunya diletakkan sebelum karburator.

Gambar 2. Rancangan Ekperimen

\subsection{Instrumen Penelitian}

Instrumen penelitian yang akan digunakan adalah inertia chassis dynamometer, exhaust gas analyzer, oxygen sensor, tachometer, dan oil temperature meter. exhaust gas analyzer digunakan untuk mengukur emisi gas buang yang dihasilkan saat pengujian.

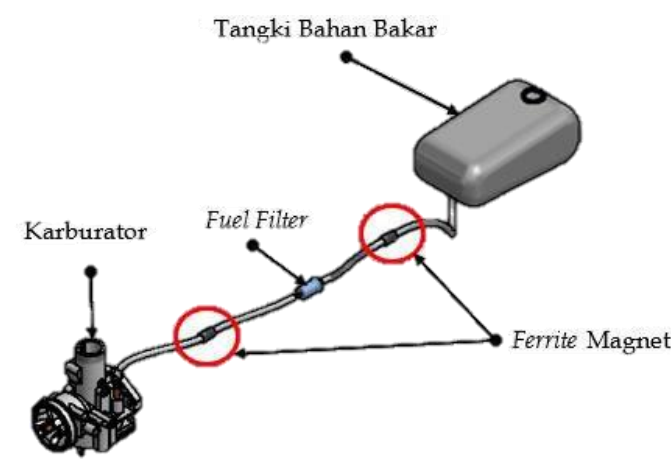

Gambar 3. Instrumen Penelitian

Keterangan:

a. Sepeda Motor Honda Supra X 125R

b. Inertia Chassis Dynamometer

c. Blower

d Layar $P C$

e. Computer (PC)

f. 4 in 1 Multi-Function Environment Meter

g. Exhaust Gas Analyzer

h. Ferrite Magnet 


\subsection{Metode Pengujian}

Metode yang digunakan dalam penelitian ini berdasarkan standar SNI 197118.3-2005 dengan pengukuran emisi gas buang pada kendaraan berbahan bakar bensin yang dilakukan pada kondisi idle. Namun untuk penelitian dapat juga dilakukan pengujian pada bukaan katup (throttle) yang berubah yang menggunakan metode pengujian kecepatan berubah dengan katup (throttle) terbuka penuh [5].

\section{HASIL DAN PEMBAHASAN}

Data hasil pengujian emisi gas buang sepeda motor yang menggunakan bahan bakar pertalite (oktan 90) dan bahan bakar pertamax (oktan 92) Sebelum dan Sesudah penambahan ferrite magnet pada saluran bahan bakar sepeda motor yang meliputi $\mathrm{HC}, \mathrm{CO}, \mathrm{CO}_{2}$, dan $\mathrm{O}_{2}$.

\subsection{Analisa Data Emisi Gas HC}

Dari pengujian yang telah dilakukan, didapatkan data emisi gas HC sebagai berikut:

Tabel 1. Data Rata - Rata Pengujian Emisi Gas HC Sebelum dan Sesudah Penambahan Ferrite Magnet

Pada Bahan Bakar Pertalite dan Pertamax

\begin{tabular}{|c|c|c|c|c|c|c|c|}
\hline \multirow{2}{*}{ RPM } & \multirow{2}{*}{$\begin{array}{c}\text { Lambda } \\
(\lambda)\end{array}$} & \multicolumn{2}{|c|}{ Standar } & \multicolumn{2}{|c|}{ Ferrite Magnet } & \multicolumn{2}{|c|}{$\begin{array}{c}\text { Presentase } \\
\text { Perubahan Gas } \\
\text { HC }(\%)\end{array}$} \\
\hline & & $\begin{array}{l}\text { Standar } \\
\text { Pertalite }\end{array}$ & \begin{tabular}{|c|} 
Standart \\
Pertamax
\end{tabular} & $\begin{array}{c}\text { Ferite } \\
\text { Pertalite }\end{array}$ & $\begin{array}{c}\text { Ferrite } \\
\text { Pertamax }\end{array}$ & Pertalite & Pertamax \\
\hline 1000 & 2,000 & 334 & 251 & 390 & 353 & 16,77 & 40,64 \\
\hline 2000 & 1,958 & 136 & 153 & 236 & 124 & 73,53 & $-18,95$ \\
\hline 3000 & 1,484 & 509 & 382 & 544 & 465 & 6,88 & 21,73 \\
\hline 4000 & 1,148 & 292 & 287 & 562 & 401 & 92,47 & 39,72 \\
\hline 5000 & 0,957 & 255 & 225 & 300 & 280 & 17,65 & 24,44 \\
\hline 6000 & 0,848 & 258 & 220 & 257 & 257 & $-0,39$ & 16,82 \\
\hline 7000 & 0,847 & 136 & 130 & 195 & 172 & 43,38 & 32,31 \\
\hline 8000 & 0,838 & 74 & 78 & 145 & 105 & 95,95 & 34,62 \\
\hline 9000 & 0,823 & 95 & 65 & 192 & 89 & 102,11 & 36,92 \\
\hline \multicolumn{6}{|c|}{ Rata - Rata Perubahan } & 49,81 & 25,36 \\
\hline
\end{tabular}

Selanjutnya dari tabel 1 diatas, data tersebut ditampilkan dalam bentuk grafik perbandingan seperti gambar dibawah ini.

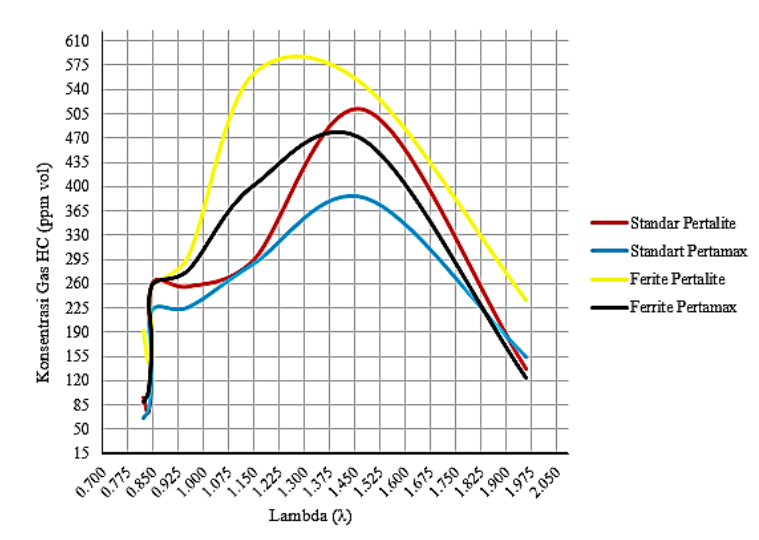

Gambar 4. Grafik Perbandingan Konsentrasi Emisi Gas HC Terhadap Lambda Sebelum dan Sesudah Penambahan Ferrite Magnet Pada Bahan Bakar Pertalite dan Pertamax

Berdasarkan grafik hasil pengujian pada Gambar 4 menunjukkan bahwa adanya perbedaan kadar HC (hydrocarbon) antara Sebelum dan Sesudah penambahan ferrite magnet baik itu yang menggunakan bahan bakar pertalite maupun bahan bakar pertamax. Kadar emisi gas $\mathrm{HC}$ saat menggunakan ferrite magnet mengalami kenaikan dibandingkan ketika tanpa ferrite magnet. Ketika menggunakan bahan bakar pertalite kadar HC maksimum yang dihasilkan adalah sebesar 562 ppm vol pada lambda 1,194 ketika penambahan ferrite magnet, sedangkan tanpa penambahan ferrite magnet kadar HC maksimum sebesar 509 ppm vol pada lambda 1,437. Sedangkan saat menggunakan bahan bakar pertamax kadar HC maksimum tertinggi dengan ferrite magnet maupun tanpa ferrite magnet berada pada lambda 1,549 yaitu sebesar 465 ppm vol dan pada lambda 1,426 dengan kadar HC sebesar 382 ppm vol.

Kadar HC minimum yang dihasilkan baik itu dengan ferrite magnet maupun tanpa ferrite magnet saat menggunakan bahan bakar pertalite maupun pertamax cenderung berada di lambda terbawah dengan kadar HC sebesar 89 ppm vol (ferrite pertamax), $145 \mathrm{ppm}$ vol (ferrite pertalite), $74 \mathrm{ppm}$ vol (standar pertalite), dan 65 (standar pertamax).

Presentase perubahan terbesar terjadi saat menggunakan bahan bakar pertalite dengan presentase $102,11 \%$ vol sedangkan perubahan terkecil adalah sebesar $(-18,95 \%$ vol $)$ saat 
menggunakan bahan bakar pertamax. Kesimpulan dari gambar grafik 5.8 terdapat perbedaan kadar HC ketika adanya penambahan ferrite magnet baik itu menggunakan bahan bakar pertalite maupun bahan bakar pertamax. Sepeda motor yang dalam pengujian menggunakan ferrite magnet memiliki kadar HC yang lebih tinggi dibandingkan yang tanpa menggunakan ferrite magnet. Semakin rpm di naikkan maka kadar HC yang di dapatkan akan semakin rendah yang mana ditunjukkan pada saat menggunakan bahan bakar Pertalite dan Pertamax.

Untuk mengetahui apakah hasil pengujian gas HC yang telah dilakukan sesuai dengan standar Peraturan Menteri Negara Lingkungan Hidup No. 05 Tahun 2006, Maka dilakukan perbandingan seperti berikut ini [6].

Tabel 2. Data Perbandingan Hasil Pengujian Gas HC Dengan Peraturan Menteri Negara Lingkungan Hidup No. 05 Tahun 2006

\begin{tabular}{|c|c|c|c|c|}
\hline Kategori: & Seped & $\begin{array}{l}\text { Lotor } 4 \\
\mathrm{kah}\end{array}$ & $\begin{array}{r}\text { Stand } \\
\mathrm{HC} \text { (pp }\end{array}$ & 2000 \\
\hline $\begin{array}{c}\text { Tahun } \\
\text { Produksi: }\end{array}$ & & & Metoc & idle \\
\hline \multicolumn{2}{|c|}{ Kelompok Pengujian: } & \multicolumn{2}{|c|}{$\begin{array}{l}\text { Hasil Pengujian } \\
\text { (ppm vol) }\end{array}$} & Keterangan \\
\hline \multicolumn{2}{|c|}{ Standar Pertalite } & \multicolumn{2}{|c|}{334} & Lolos \\
\hline \multicolumn{2}{|c|}{ Standar Pertamax } & \multicolumn{2}{|c|}{382} & Lolos \\
\hline \multicolumn{2}{|c|}{ Ferrite Pertalite } & \multicolumn{2}{|c|}{562} & Lolos \\
\hline \multicolumn{2}{|c|}{ Ferrite Pertamax } & \multicolumn{2}{|c|}{465} & Lolos \\
\hline
\end{tabular}

Dari data perbandingan yang telah dilakukan dapat diketahui bahwa hasil pengujian kadar emisi gas HC yang telah dilakukan masih dalam ambang batas yang telah ditentukan oleh Peraturan Menteri Negara Lingkungan Hidup No. 05 Tahun 2006 Tentang Ambang Batas Emisi Gas Buang Kendaraan Lama sehingga hasil pengujian kadar emisi gas $\mathrm{HC}$ dapat dinyatakan lolos hasil pengujian.

\subsection{Analisa Data Emisi Gas CO}

Dari pengujian yang telah dilakukan, didapatkan data emisi gas CO sebagai berikut.

Tabel 3. Data Rata - Rata Pengujian Emisi Gas CO Sebelum dan Sesudah Penambahan Ferrite Magnet Pada Bahan Bakar Pertalite dan Pertamax
Dari tabel 3 diatas, data tersebut ditampilkan dalam bentuk grafik perbandingan seperti

\begin{tabular}{|c|c|c|c|c|c|c|c|}
\hline \multirow{2}{*}{ RPM } & \multirow{2}{*}{$\begin{array}{c}\text { Lambda } \\
(A)\end{array}$} & \multicolumn{2}{|c|}{ Standar } & \multicolumn{2}{c|}{ Ferrite Magnet } & \multicolumn{2}{c|}{$\begin{array}{c}\text { Presentase } \\
\text { Perubahan Gas } \\
\text { CO (\%) }\end{array}$} \\
\cline { 3 - 8 } & & $\begin{array}{c}\text { Standar } \\
\text { Pertalite }\end{array}$ & $\begin{array}{c}\text { Standart } \\
\text { Pertamax }\end{array}$ & $\begin{array}{c}\text { Ferite } \\
\text { Pertalite }\end{array}$ & $\begin{array}{c}\text { Ferrite } \\
\text { Pertamax }\end{array}$ & Pertalite & Pertamax \\
\hline 1000 & 2,000 & 1,28 & 1,10 & 1,30 & 1,00 & 1,56 & $-9,09$ \\
\hline 2000 & 1,958 & 3,04 & 1,49 & 1,87 & 1,64 & $-38,49$ & 10,07 \\
\hline 3000 & 1,484 & 4,39 & 4,17 & 3,99 & 3,63 & $-9,11$ & $-12,95$ \\
\hline 4000 & 1,148 & 6,22 & 6,04 & 5,58 & 5,30 & $-10,29$ & $-12,25$ \\
\hline 5000 & 0,957 & 7,45 & 7,29 & 7,07 & 6,55 & $-5,10$ & $-10,15$ \\
\hline 6000 & 0,848 & 8,53 & 8,10 & 8,10 & 7,63 & $-5,04$ & $-5,80$ \\
\hline 7000 & 0,847 & 8,19 & 7,83 & 8,06 & 6,90 & $-1,59$ & $-11,88$ \\
\hline 8000 & 0,838 & 6,99 & 7,36 & 7,40 & 5,68 & 5,87 & $-22,83$ \\
\hline 9000 & 0,823 & 7,88 & 8,53 & 8,14 & 5,96 & 3,30 & $-30,13$ \\
\hline \multicolumn{3}{|c|}{ Rata - Rata Perubahan } & & $-\mathbf{6 , 5 4}$ & $-\mathbf{1 1 , 6 7}$ \\
\hline
\end{tabular}

gambar dibawah ini.

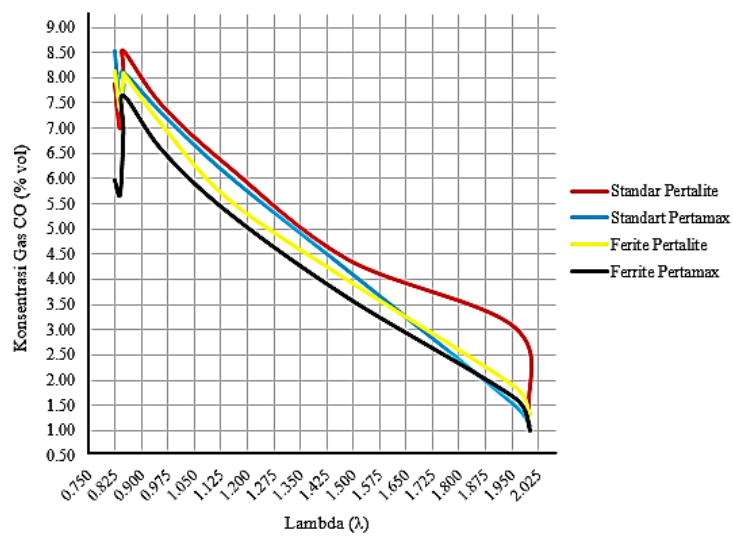

Gambar 5. Grafik Perbandingan Konsentrasi Emisi Gas CO Terhadap Lambda Sebelum dan Sesudah Penambahan Ferrite Magnet Pada Bahan Bakar Pertalite dan Pertamax

Berdasarkan grafik hasil pengujian pada data diatas menunjukkan bahwa adanya peningkatan kadar CO (karbon monosida) pada saat pengujian. Ketika menggunakan bahan bakar pertalite dan bahan bakar pertamax kadar CO tertinggi yang dihasilkan sama-sama sebesar $8.53 \%$ vol namun pada lambda yang berbeda. Ketika adanya penambahan ferrite magnet, terjadi perubahan kadar $\mathrm{CO}$ yang dihasilkan baik itu menggunakan bahan bakar pertalite maupun bahan bakar pertamax. Saat menggunakan bahan bakar pertalite kadar CO tertinggi dihasilkan sebesar $8.14 \%$ vol pada lambda 0,83 . Sedangkan saat menggunakan bahan bakar pertamax kadar CO tertinggi dihasilkan menjadi $7.63 \%$ vol pada lambda 0,85 .

Dari data diatas dapat diketahui bahwa semakin rendah nilai lambdanya maka kadar $\mathrm{CO}$ yang dihasilkan semakin meningkat. Namun, dengan adanya penambahan ferrite magnet pada 
fuel hose terjadi perubahan kadar $\mathrm{CO}$ yang dihasilkan sepeda motor. Kesimpulan dari Gambar 4.5 terdapat perbedaan kadar CO antara sebelum dan sesudah penambahan ferrite magnet. Sepeda motor yang menggunakan ferrite magnet memiliki kadar $\mathrm{CO}$ lebih rendah dibandingkan sepeda motor yang tanpa menggunakan ferrite magnet baik itu yang menggunakan bahan bakar pertalite maupun bahan bakar pertamax. Selain itu ketika menggunakan kedua bahan bakar tersebut apabila nilai lambdanya menurun maka kadar $\mathrm{CO}$ yang dihasilkan akan semakin tinggi.

Untuk mengetahui apakah hasil pengujian gas CO yang telah dilakukan sesuai dengan standar Peraturan Menteri Negara Lingkungan Hidup No. 05 Tahun 2006, Maka dilakukan perbandingan seperti berikut ini [6].

Tabel 4. Data Perbandingan Hasil Pengujian Gas HC Dengan Peraturan Menteri Negara Lingkungan Hidup No. 05 Tahun 2006

\begin{tabular}{c|c|c|c}
\hline Kategori: & $\begin{array}{c}\text { Sepeda Motor 4 } \\
\text { Langkah }\end{array}$ & $\begin{array}{c}\text { Standar Gas } \\
\text { CO (\% vol): }\end{array}$ & 4,5 \\
\hline $\begin{array}{c}\text { Tahun } \\
\text { Produksi: }\end{array}$ & \multicolumn{2}{|c|}{2011} & \multicolumn{2}{c}{ Metode test: } & idle \\
\hline Kelompok Pengujian: & $\begin{array}{c}\text { Hasil Pengujian } \\
\text { (ppm vol) }\end{array}$ & Keterangan \\
\hline Standar Pertalite & 8,53 & Tidak Lolos \\
\hline Standar Pertamax & 8,53 & Tidak Lolos \\
\hline Ferrite Pertalite & 8,14 & Tidak Lolos \\
\hline Ferrite Pertamax & 7,65 & & Tidak Lolos \\
\hline
\end{tabular}

Dari data perbandingan yang telah dilakukan dapat diketahui bahwa hasil pengujian kadar emisi gas CO yang telah dilakukan telah melewati ambang batas yang telah ditentukan oleh Peraturan Menteri Negara Lingkungan Hidup No. 05 Tahun 2006 Tentang Ambang Batas Emisi Gas Buang Kendaraan Lama sehingga hasil pengujian kadar emisi gas $\mathrm{CO}$ dapat dinyatakan tidak lolos hasil pengujian.

\subsection{Analisa Data Emisi Gas $\mathrm{CO}_{2}$}

Dari pengujian yang telah dilakukan, didapatkan data emisi gas $\mathrm{CO}_{2}$ sebagai berikut.
Tabel 5. Data Rata - Rata Pengujian Emisi Gas $\mathrm{CO}_{2}$ Sebelum dan Sesudah Penambahan Ferrite

\begin{tabular}{|c|c|c|c|c|c|c|c|}
\hline \multirow{2}{*}{ RPM } & \multirow{2}{*}{$\begin{array}{c}\text { Lambda } \\
(\boldsymbol{\lambda})\end{array}$} & \multicolumn{2}{|c|}{ Standar } & \multicolumn{2}{c|}{$\begin{array}{c}\text { Ferrite Magnet } \\
\text { Presentase }\end{array}$} & \multicolumn{2}{c|}{$\begin{array}{c}\text { Perubahan Gas CO } \\
\text { (\%) }\end{array}$} \\
\cline { 3 - 8 } & & $\begin{array}{c}\text { Standar } \\
\text { Pertalite }\end{array}$ & $\begin{array}{c}\text { Standart } \\
\text { Pertamax }\end{array}$ & $\begin{array}{c}\text { Ferite } \\
\text { Pertalite }\end{array}$ & $\begin{array}{c}\text { Ferrite } \\
\text { Pertamax }\end{array}$ & Pertalite & Pertamax \\
\hline 1000 & 2.000 & 3.30 & 3.30 & 3.10 & 2.80 & -6.06 & -15.15 \\
\hline 2000 & 1.958 & 4.40 & 3.80 & 3.40 & 3.50 & -22.73 & -7.89 \\
\hline 3000 & 1.484 & 4.90 & 5.40 & 4.40 & 4.50 & -10.20 & -16.67 \\
\hline 4000 & 1.148 & 5.90 & 6.00 & 5.20 & 5.40 & -11.86 & -10.00 \\
\hline 5000 & 0.957 & 6.80 & 7.10 & 6.10 & 6.50 & -10.29 & -8.45 \\
\hline 6000 & 0.848 & 7.50 & 7.80 & 7.00 & 7.00 & -6.67 & -10.26 \\
\hline 7000 & 0.847 & 6.30 & 8.20 & 7.30 & 7.80 & 15.87 & -4.88 \\
\hline 8000 & 0.838 & 6.40 & 8.60 & 7.70 & 9.30 & 20.31 & 8.14 \\
\hline 9000 & 0.823 & 5.70 & 8.60 & 6.80 & 10.80 & 19.30 & 25.58 \\
\hline \multicolumn{3}{|c|}{ Rata - Rata Perubahan } \\
\hline
\end{tabular}

Dari tabel 5 diatas, data tersebut ditampilkan dalam bentuk grafik perbandingan seperti gambar dibawah ini.

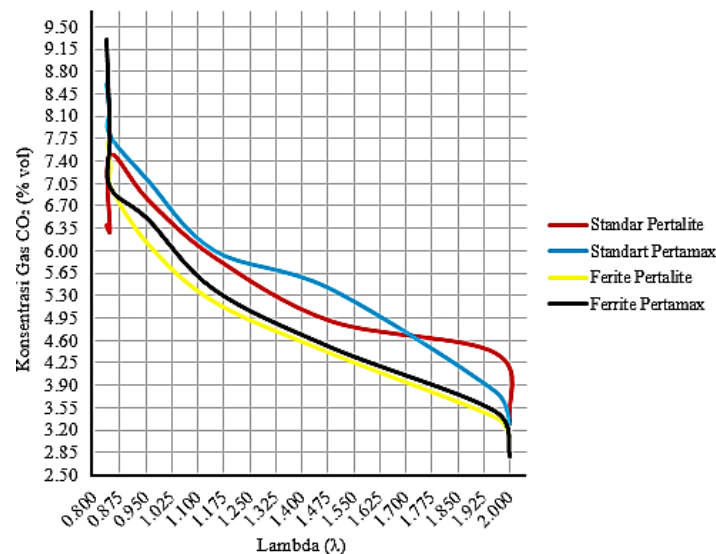

Gambar 6. Grafik Perbandingan Konsentrasi Emisi Gas $\mathrm{CO}_{2}$ Terhadap Lambda Sebelum dan Sesudah Penambahan Ferrite Magnet Pada Bahan Bakar Pertalite dan Pertamax

Untuk melihat perbedaan Kadar $\mathrm{CO}_{2}$ pada sepeda motor Sebelum dan Sesudah penambahan ferrite magnet bisa dilihat pada data penelitian diatas. Pada data diatas dapat dilihat kadar $\mathrm{CO}_{2}$ tertinggi yang dihasilkan saat menggunakan pertalite adalah sebesar $7.50 \%$ ppm vol pada lambda 0,84 , namun setelah itu kadar $\mathrm{CO}_{2}$ yang dihasilkan terus menurun hingga mencapai $5.70 \%$ pada lambda 0,77 . Sedangkan kadar $\mathrm{CO}_{2}$ yang dihasilkan menggunakan pertamax mulai dari lambda awal terus mengalami kenaikan hingga pada nilai lambda 0,83 kadar $\mathrm{CO}_{2}$ yang dihasilkan sebesar $8.60 \%$. Setelah adanya penambahan ferrite magnet yang bisa dilihat pada data tersebut terjadi perubahan kadar $\mathrm{CO}_{2}$ yang dihasilkan sepeda motor baik itu yang 
menggunakan bahan bakar pertalite maupun pertamax.

Ketika menggunakan bahan bakar pertalite dan adanya penambahan ferrite magnet, terjadi perubahan kadar $\mathrm{CO}_{2}$ yang dihasilkan ketimbang sebelum penambahan ferrite magnet. Perubahan ini terjadi mulai lambda awal hingga $6000 \mathrm{rpm}$ dengan lambda 0,84 , namun pada nilai lambda 0,83 kadar $\mathrm{CO}_{2}$ meningkat melebihi kadar $\mathrm{CO}_{2}$ sebelumnya hingga mencapai $7.70 \%$ vol dan barulah terjadi penurunan kembali hingga mencapai 0,83 dengan kadar $\mathrm{CO}_{2}$ yang dihasilkan sebesar $6.80 \%$ vol. Hal serupa juga terjadi ketika penambahan ferrite magnet saat menggunakan bahan bakar pertamax. Perubahan juga terjadi di lambda awal hingga mencapai lambda akhir yang mana kadar $\mathrm{CO}_{2}$ terus meningkat hingga kadar $\mathrm{CO}_{2}$ yang dihasilkan mencapai $10.80 \%$ vol pada lambda 0,86 .

Dari data tersebut dapat kita ketahui bahwa dengan adanya penambahan ferrite magnet dapat mempengaruhi kadar $\mathrm{CO}_{2}$ yang dihasilkan oleh sepeda motor meskipun pada nilai lambda yang lebih besar cenderung kadar $\mathrm{CO}_{2}$ yang dihasilkan lebih tinggi dibanding sebelum penambahan ferrite magnet. Selain itu perbedaan bahan bakar yang digunakan juga mempengaruhi kadar $\mathrm{CO}_{2}$ yang dihasilkan sepeda motor yang mana bisa dilihat perubahan kadar $\mathrm{CO}_{2}$ terbesar dan terkecil terjadi ketika menggunakan bahan bakar pertalite dengan presentase $22,73 \%$ vol dan $(-20,31 \%$ vol). Kadar $\mathrm{CO}_{2}$ yang menggunakan pertalite cenderung naik turun/ tidak stabil, sedangkan saat menggunakan bahan bakar pertamax kadar $\mathrm{CO}_{2}$ cenderung terus mengalami kenaikan pada saat nilai lambda ikut naik.

\subsection{Analisa Data Emisi Gas $\mathrm{O}_{2}$}

Dari pengujian yang telah dilakukan, didapatkan data emisi gas $\mathrm{O}_{2}$ sebagai berikut.

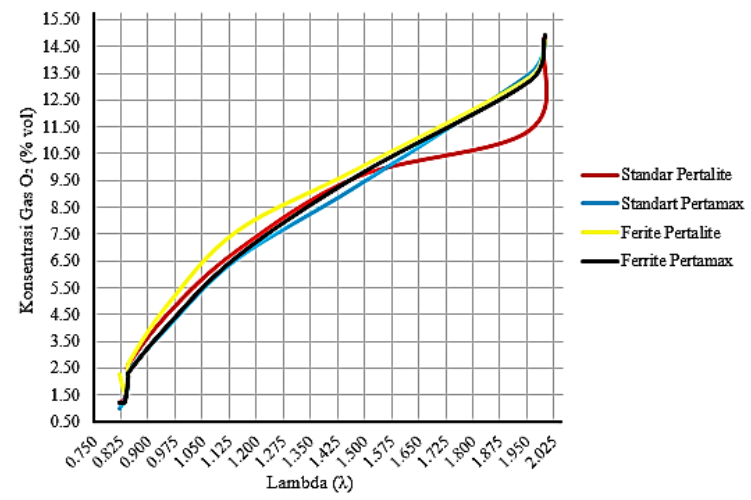

Gambar 7. Grafik Perbandingan Konsentrasi Emisi Gas $\mathrm{O}_{2}$ Terhadap Lambda Sebelum dan Sesudah Penambahan Ferrite Magnet Menggunakan Bahan Bakar Pertalite dan Pertamax

Berdasarkan grafik hasil pengujian pada data diatas menunjukkan bahwa adanya perubahan kadar $\mathrm{O}_{2}$ (oksigen) baik itu sebelum dan sesudah penambahan ferrite magnet saat menggunakan bahan bakar pertalite maupun bahan bakar pertamax. Hal ini di buktikan kadar $\mathrm{O}_{2}$ tertinggi yang dihasilkan saat menggunakan bahan bakar pertalite ada pada lambda 2,00 yaitu sebesar $14,84 \%$ vol sedangkan yang paling rendah ada pada lambda 0,77 dengan kadar $\mathrm{O}_{2}$ sebesar $1,18 \%$. Ketika menggunakan bahan bakar pertamax kadar $\mathrm{O}_{2}$ tertinggi yang dihasilkan sebesar $14,56 \%$ vol pada nilai lambda 2,00 sedangkan yang paling rendah adalah $1.01 \%$ vol pada lambda 0,83 . Pada saat penambahan ferrite magnet kadar $\mathrm{O}_{2}$ juga mengalami perubahan yang mana saat menggunakan bahan bakar pertalite maupun pertamax kadar $\mathrm{O}_{2}$ tertinggi ada pada lambda awal yaitu sebesar $14.74 \%$ vol (ferrite pertalite) dan $14.91 \%$ vol (ferrite pertamax) sedangkan kadar $\mathrm{O}_{2}$ terendah berada di lambda 0,83 sebesar $1.56 \%$ vol (ferrite pertalite) dan sebesar $1.22 \%$ vol (ferrite pertamax) pada lambda 0,86 .

Dari data diatas diketahui, tidak terdapat perbedaan yang signifikan ketika sebelum dan sesudah penambahan ferrite magnet saat menggunakan bahan bakar pertalite maupun pertamax. Dari data tersebut, sepeda motor yang menggunakan bahan bakar pertamax memiliki kadar $\mathrm{O}_{2}$ lebih besar dibandingkan saat menggunakan bahan bakar pertalite. Hal ini membuktikan bahwa semakin rendah nilai lambdanya maka kadar $\mathrm{O}_{2}$ juga akan ikut turun. 


\subsection{Analisa Data Lambda}

Dari pengujian yang telah dilakukan, didapatkan data perubahan lambda sebagai berikut.

Tabel 7. Data Rata - Rata Perubahan Lambda Sebelum dan Sesudah Penambahan Ferrite Magnet Pada Bahan Bakar Pertalite dan Pertamax

\begin{tabular}{|c|c|c|c|c|c|c|c|}
\hline \multirow{3}{*}{$\begin{array}{c}\text { Pengujian } \\
\text { (RPM) }\end{array}$} & \multicolumn{7}{|c|}{ Jenis Pengujian (RPM Terhadap Lambda) } \\
\hline & \multicolumn{2}{|c|}{$\begin{array}{c}\text { Lambda }(\lambda) \\
\text { Kelompok Standar }\end{array}$} & \multicolumn{2}{|c|}{$\begin{array}{c}\text { Lambda }(\lambda) \\
\text { Kelompok Eksperimen }\end{array}$} & \multirow{2}{*}{$\begin{array}{c}\text { Rata -rata } \\
\text { Lambda }(\lambda) \\
\text { Keseluruhan }\end{array}$} & \multicolumn{2}{|c|}{$\begin{array}{l}\text { Presentase Perubahan } \\
\text { Lambda }(\lambda)\end{array}$} \\
\hline & $\begin{array}{l}\text { Standar } \\
\text { Pertalite }\end{array}$ & $\begin{array}{l}\text { Standar } \\
\text { Pertamax }\end{array}$ & $\begin{array}{l}\text { Ferrite } \\
\text { Pertalite }\end{array}$ & $\begin{array}{l}\text { Ferrite } \\
\text { Pertamax }\end{array}$ & & Pertalite & Pertanax \\
\hline 1000 & 2,000 & 2,000 & 2,000 & 2,000 & 2,000 & 0,000 & 0,000 \\
\hline 2000 & 1,833 & 2,000 & 2,000 & 2,000 & 1,958 & 9,111 & 0,000 \\
\hline 3000 & 1,437 & 1,426 & 1,523 & 1,549 & 1,484 & 5,985 & 8,626 \\
\hline 4000 & 1,122 & 1,115 & 1,194 & 1,160 & 1,148 & 6,417 & 4,036 \\
\hline 5000 & 0,952 & 0,938 & 0,977 & 0,960 & 0,957 & 2,626 & 2,345 \\
\hline 6000 & 0,843 & 0,850 & 0,850 & 0,847 & 0,848 & 0,830 & $-0,353$ \\
\hline 7000 & 0,822 & 0,848 & 0,842 & 0,876 & 0,847 & 2,433 & 3,302 \\
\hline 8000 & 0,814 & 0,836 & 0,830 & 0,871 & 0,838 & 1,966 & 4,187 \\
\hline 9000 & 0,768 & 0,830 & 0,830 & 0,863 & 0,823 & 8,073 & 3,976 \\
\hline
\end{tabular}

Dari Tabel 7 diatas, data tersebut ditampilkan dalam bentuk grafik perbandingan seperti gambar dibawah ini.

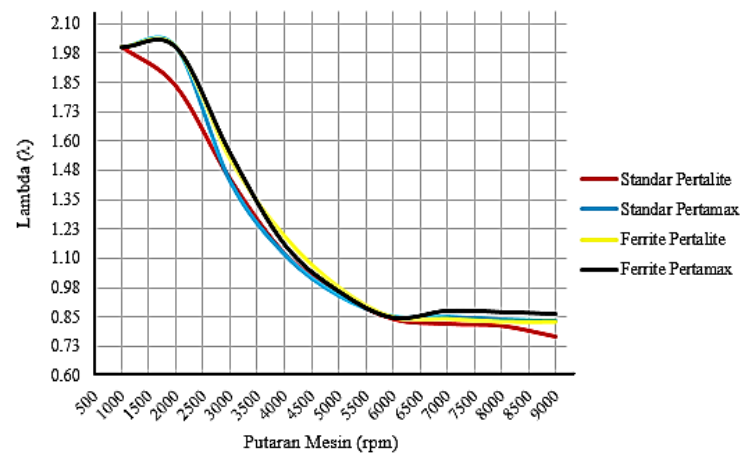

Gambar 8. Grafik Perbandingan Pengaruh Lambda Terhadap rpm Sebelum dan Sesudah Penambahan Ferrite Magnet Menggunakan Bahan Bakar Pertalite

Berdasarkan data hasil pengujian di atas menunjukkan perubahan lambda yang terjadi pada tiap-tiap peningkatan rpm. Nilai lambda sendiri berkaitan dengan perbandingan antara campuran udara dan bahan bakar yang terbuang lewat asap knalpot. Berdasarkan data tersebut diketahui bahwa setiap rpm naik maka lambda yang dihasilkan akan semakin menurun. Hal ini dibuktikan, ketika menggunakan bahan bakar pertalite pada rpm awal nilai lambda yang dihasilkan 2,00, pada saat $2000 \mathrm{rpm}$ besar nilai lambdanya 1,833 , pada saat $3000 \mathrm{rpm}$ besar nilai lambdanya 1,437 , dan terus menurun hingga pada $9000 \mathrm{rpm}$ nilai lambdanya sebesar 0,768 .
Perubahan tersebut juga terjadi ketika menggunakan bahan bakar pertamax. Pada 1000 dan 2000 rpm nilai lambda yang dihasilkan 2,00. Pada saat $3000 \mathrm{rpm}$ besar nilai lambdanya mulai menurun hingga mencapai 1,426. Saat $4000 \mathrm{rpm}$ besar nilai lambdanya 1,115 , dan terus menurun hingga pada $9000 \mathrm{rpm}$ nilai lambdanya sebesar 0,830 .

Pada saat penambahan ferrite magnet besar nilai lambdanya juga menurun, namun masih ada sedikit peningkatan dibandingkan sebelumnya. Ketika menggunakan bahan bakar pertalite besar nilai lambdanya masih stabil pada angka 2,00 pada saat 1000 dan $2000 \mathrm{rpm}$. Sedangkan pada 3000 rpm baru terjadi Perubahan nilai lambda hingga mencapai 1,549 . Perubahan terus terjadi hingga pada $9000 \mathrm{rpm}$ besar nilai lambdanya adalah 0,830. Saat menggunakan bahan bakar pertamax, pada 1000 dan $2000 \mathrm{rpm}$ nilai lambda yang dihasilkan masih stabil di angka 2,00. Pada saat $3000 \mathrm{rpm}$ besar mulai terjadi Perubahan hingga nilai lambdanya mencapai 1,549 . Saat $4000 \mathrm{rpm}$ besar nilai lambdanya 1,160 , dan terus menurun hingga pada $9000 \mathrm{rpm}$ nilai lambdanya sebesar 0,863 .

Dari data-data diatas dapat kita simpulkan bahwa besar nilai lambda yang dihasilkan pada pengujian cenderung terus menurun meskipun menggunakan bahan bakar pertalite maupun pertamax. Setelah ditambahkan ferrite magnet, terjadi sedikit peningkatan pada nilai lambda yang dihasilkan walaupun peningkatannya tidak terlalu signifikan. Hal ini membuktikan bahwa dengan adanya penambahan ferrite magnet pada fuel hose maka akan berpengaruh terhadap emisi gas buang yang dihasilkan sehingga gas buang yang dihasilkan dari kendaraan dapat dimaksimalkan.

\section{KESIMPULAN}

Dari hasil penelitian pengaruh pemasangan ferrite magnet pada saluran bahan bakar terhadap emisi gas buang four stroke engine $125 \mathrm{cc}$ dapat diambil kesimpulan sebagai berikut:

1. Pemasangan ferrite magnet pada kendaraan four stroke engine $125 \mathrm{cc}$ dapat mempengaruhi emisi gas buang kendaraan 
yang dihasilkan saat menggunakan bahan bakar pertalite maupun pertamax.

2. Kadar emisi gas buang tertinggi untuk gas HC adalah 562 ppm vol (ferrite pertalite) dengan presentase perubahan terbesar sebanyak $102,11 \%$. Untuk kadar emisi gas CO tertinggi adalah $8,53 \%$ saat menggunakan pertalite maupun pertamax dengan presentase perubahan terbesar sebanyak $38,49 \%$. Untuk kadar emisi gas $\mathrm{CO}_{2}$ adalah $10,80 \%$ (ferrite pertamax) dengan presentase perubahan terbesar sebanyak $22,73 \%$. Sedangkan pada emisi gas $\mathrm{O}_{2}$ kadar emisinya sebesar $14,91 \%$ (ferrite pertalite) dengan presentase perubahan terbesar sebanyak $91,53 \%$.

\section{REFERENSI}

[1] Ismawan, Alim Kurnia, Dkk, "Pengaruh Pemasangan Alat Peningkat Kualitas Bahan Bakar Terhadap Unjuk Kerja Dan Konsumsi Bahan Bakar Spesifik Motor Bensin". Jurnal Fakultas Teknik. MEDIA MESIN, Vol. 11, No. 1, Januari 2010, 30 - 36 ISSN 1411-4348. Jurusan Teknik Mesin. Universitas Muhammadiyah. Surakarta, 2010.

[2] Helmi, Yuda, "Pengaruh Variasi Campuran Bahan Bakar Pertalite Dan Bioetanol Terhadap Prestasi Mesin Dan Emisi Gas Buang Mesin Bensin 4 Langkah Tecquipment Td201". Skripsi. Fakultas Teknik. Universitas Lampung. Bandar Lampung, 2018.

[3] Afza, E., Pembuatan Magnet Permanen BaHexa Ferrite (BaO.6Fe2O3) dengan Metode Koopresipitasi dan Karakterisasinya, Skripsi, Fakultas Matematika dan Ilmu Pengetahuan Alam, Universitas Sumatera Utara, Medan, 2011

[4] Sudirman, Urip, Metode Tepat Menghemat Bahan Bakar (Bensin) Mobil. Penerbit: KAWAN PUSTAKA, 2006.

[5] Warju, dkk, The Performance of ChromeCoated Copper as Metallic Catalytic Converter to Reduce Exhaust Gas Emissions from SparkIgnition Engine. In IOP Conference Series: Materials Science and Engineering (Vol. 288, No. 1, p. 012151). IOP Publishing, 2018.

[6] Menteri Lingkungan Hidup, Peraturan Menteri No. 05 Tahun 2006 Tentang Ambang Batas Emisi Gas Buang Kendaraan Lama. Lembaran
RI Tahun 2006 No. 05. Jakarta: Sekretariat Negara, 2006. 